\title{
A NOVA LEI DE PATENTES, A INDÚSTRIA QUÍMICA E A UNIVERSIDADE
}

\author{
Alexandre de Oliveira Rodrigues* \\ Rua Estácio Coimbra, 47/401 - Botafogo - 22260-010 - Rio de Janeiro - RJ
}

Recebido em 26/2/97; aceito em 15/9/97

\begin{abstract}
THE NEW PATENT LAW, THE CHEMICAL INDUSTRY AND THE UNIVERSITY. This paper aims to present some features of the Industrial Property Law now in force in Brazil, as far as they could be regarded to the activities of research and development in the field of Chemistry and related areas, not only in the chemical industry but also in the university. By means of analysis of the main articles and paragraphs, which could deal with the mentioned activities, the author points out the scope and limitations of that law and explains the meaning of common technical terms usually found in patent concerns. Ultimately, a brief discussion on the actual and the potential role of the Brazilian university in the sphere of the Industrial Property is made.
\end{abstract}

Keywords: patent; university; chemical industry; law.

\section{INTRODUÇÃO}

A lei 9.279 (de 14.05.96), publicada no Diário Oficial da União de 15.05 .96 (págs. 8.353 a 8.366 ), que entrou em vigor em 15.05.97, conhecida como a "Lei das Patentes", nos seus 244 artigos, na verdade é bem mais ampla do que sugere o nome que a popularizou.

Além disso, desde os seus primeiros anteprojetos, essa lei foi bastante discutida, combatida e defendida, criando-se muita polêmica em diversos setores, mas, principalmente, naqueles ligados às indústrias químicas em geral, e às indústrias farmacêuticas e de Biotecnologia, em particular.

Os objetivos do presente trabalho são dois. Primeiro, gostaria de partilhar com o leitor alguns conhecimentos adquiridos durante os quatro anos em que atuei como analista de patentes, bem como introduzir (de modo bem sucinto) os conceitos básicos envolvidos na legislação patentária. Segundo, creio que essa minha experiência, aliada a algum senso crítico, me permitem fazer algumas apreciações e sugestões no que se refere aos reflexos e às implicações da dita legislação no âmbito da indústria química e da Universidade brasileiras.

Tais apreciações e sugestões referentes à indústria química são evidentes pelo próprio teor dos artigos analisados. Já no que se refere à Universidade, ousei fazer um pouco mais, conforme poderá ser lido mais adiante.

\section{A NOVA LEI DE PROPRIEDADE INDUSTRIAL (LEI 9.279, DE 14.05.96)}

Nas partes que se seguem, apresentarei os artigos, os incisos e os parágrafos relevantes ao profissional de química, seguidos de comentários que visam a melhor esclarecer a terminologia algo estranha do texto legal, bem como a elucidar alguns conceitos e princípios por trás do mesmo. Detalhes adicionais relativos a casos específicos, poderão ser encontrados nos demais artigos da lei em estudo.

O termo "objeto", conforme aqui utilizado, se refere a qualquer ente que possa ser matéria de uma patente (um processo, uma família de moléculas químicas, uma aplicação, etc.).

Um fato que merece destaque é que uma patente (mais precisamente, uma carta-patente) é um documento concedido pelo

* Engenheiro Químico / Consultor governo de um país ou grupo de países (no caso de acordos internacionais sobre a matéria) e que só têm validade ou que só gera efeitos naquele país ou grupo de países. Portanto, uma patente brasileira só vale no Brasil. Freqüentemente, o leigo toma como verdadeiro o conceito de que um objeto patenteado, digamos, na Alemanha, está protegido no Brasil da exploração por terceiros. Isso não é, absolutamente, verdade.

Além disso, uma idéia pré-concebida bastante freqüente é que a comercialização de um dado objeto patenteável envolve, necessariamente, o seu patenteamento. Isso também não é verdade. Nada impede, por exemplo, que um pesquisador, que desenvolveu um dado processo químico, explore comercialmente tal processo. No entanto, sem a patente, não existirá a proteção legal que impedirá que terceiros também explorem comercialmente esse processo, tanto quanto possam ou queiram. Conforme veremos, a patente, por meio de um monopólio, delimita as fronteiras do direito de exclusividade do inventor, no que se refere à exploração do objeto em questão, impedindo que terceiros aufiram os benefícios dessa exploração desautorizada.

\section{DISPOSIÇÕES PRELIMINARES}

\section{Artigo $1^{0}$}

Essa lei regula direitos e obrigações relativos à propriedade industrial.

\section{Comentário}

A presente lei não se refere somente às patentes de invenção. Além delas, essa lei regula os direitos e obrigações relativos às patentes de modelo de utilidade, aos registros de desenhos industriais, aos registros de marcas, à repressão às falsas indicações geográficas e à repressão à concorrência desleal.

$\mathrm{O}$ leitor já deve ter ouvido a expressão modelo de utilidade em alguma ocasião. O modelo de utilidade difere da invenção, principalmente, pelo grau de inventividade envolvido. Um exemplo ajudará a elucidar tal diferença.

Até o começo desse século, eram muito comuns (senão os únicos portáteis!) os relógios de bolso. Para se ver a hora, a pessoa sacava do bolso o relógio, via as horas e tornava a colocá-lo ali. Alguns historiadores atribuem a Santos Dumont a "invenção" do relógio de pulso, tal como o conhecemos hoje em dia. Dizem que Dumont vivia com as mãos ocupadas (e, eventualmente, sujas) com suas experiências mecânicas, o que 
dificultava bastante a simples tarefa de ver as horas, nos moldes de então. Assim, para facilitar essa tarefa, ele adaptou uma correia afivelada ao seu relógio, de modo a poder prendê-lo em seu pulso. Nascia, então, esse tipo de relógio.

Ora, ao introduzir esse aperfeiçoamento no relógio de bolso, Santos Dumont não modificou a maneira pela qual a passagem do tempo era medida (por meio de uma disposição coerente de molas e engrenagens mecânicas), apenas tornou essa maneira mais prática de ser utilizada. Ele não alterou o conceito do que era um relógio. Portanto, uma patente de modelo de utilidade visa a proteger tais aperfeiçoamentos que venham a tornar mais prática uma invenção já existente.

Mais tarde, os suíços inventaram o relógio digital que, por introduzir uma maneira totalmente diferente (e, portanto, nova) de medir a passagem do tempo, foi objeto de várias patentes de invenção para suas peculiaridades técnicas.

\section{Artigo $5^{\circ}$}

Consideram-se bens móveis, para os efeitos legais, os direitos de propriedade industrial.

\section{Comentário}

Uma patente é, segundo a lei, um bem móvel (como um carro ou casa, por exemplo) e, como tal, pode ser vendido, comprado, licenciado, doado, etc.

\section{TÍTULO I: DAS PATENTES CAPÍTULO I: DA TITULARIDADE}

\section{Artigo $6^{\circ}$, parágrafo $2^{\circ}$}

A patente poderá ser requerida em nome próprio, pelos herdeiros ou sucessores do autor, pelo cessionário ou por aquele a quem a lei ou o contrato de trabalho ou de prestação de serviços determinar que pertença a titularidade.

\section{Comentário}

A lei é clara ao estabelecer que o autor (inventor), ou seus herdeiros, são os únicos que podem solicitar um pedido de patente, e somente eles. No entanto, ela ressalva que, por força das cláusulas de um contrato de trabalho ou de prestação de serviços, a titularidade (posse) da invenção terá que ser cedida, pelo inventor (cedente), a uma empresa, instituição de pesquisas ou outra pessoa física ou jurídica (cessionário).

\section{Artigo $7^{\circ}$}

Se dois ou mais autores tiverem realizado a mesma invenção ou modelo de utilidade, de forma independente, o direito de obter patente será assegurado àquele que provar o depósito mais antigo, independentemente das datas de invenção ou criação.

\section{Comentário}

Não importa o esforço anterior de pesquisa e de desenvolvimento gasto por dois ou mais inventores, será assegurado o direito de prioridade àquele que depositar primeiro o seu pedido de patente. Já houve casos em que esse direito de prioridade foi decidido por diferença de horas no carimbo de protocolo, dado pela repartição de patentes, nos respectivos pedidos de patente para um mesmo objeto. É sempre recomendável, portanto, que haja sigilo nas linhas de pesquisa e de desenvolvimento quando o seu objeto puder ser estratégico do ponto de vista comercial.

\section{CAPÍTULO II: DA PATENTEABILIDADE SEÇÃO I: DAS INVENÇÕES E DOS MODELOS DE UTILIDADE PATENTEÁVEIS}

\section{Artigo $\mathbf{8}^{\circ}$}

É patenteável a invenção que atenda aos requisitos de novidade, atividade inventiva e aplicação industrial.

\section{Comentário}

É curioso constatar que existem requisitos para que uma invenção seja considerada patenteável. Mais adiante (Artigo 18), veremos que esses são requisitos necessários, porém não suficientes para que um objeto seja patenteável.

\section{Artigo $\mathbf{1 0}^{\circ}$}

Não se considera invenção nem modelo de utilidade:

I descobertas, teorias científicas e métodos matemáticos; II concepções puramente abstratas;

III esquemas, planos, princípios ou métodos comerciais, contábeis, financeiros, educativos, publicitários, de sorteio e de fiscalização;

IV as obras literárias, arquitetônicas, artísticas e científicas ou qualquer criação estética;

$\mathrm{V}$ programas de computador em si;

VI apresentação de informações;

VII regras de jogo;

VIII técnicas e métodos operatórios ou cirúrgicos, bem como métodos terapêuticos ou de diagnóstico, para aplicação no corpo humano ou animal; e

IX o todo ou parte de seres vivos naturais e materiais biológicos encontrados na natureza, ou ainda que dela isolados, inclusive o genoma ou germoplasma de qualquer ser vivo natural e os processos biológicos naturais.

\section{Comentário}

Esse é, no meu entender, um dos artigos mais importantes da presente lei. Dos seus incisos, destaco os seguintes: I, V, VIII e IX.

O inciso I é claro ao afirmar que não é considerada invenção a simples descoberta de algo novo. Esse fato é até óbvio, pois invenção sempre pressupõe a interveniência do intelecto humano sobre os recursos da natureza somada a um certo sinergismo decorrente da inteligência do inventor. Portanto, a constatação de que existe algo novo, por si só, não possui qualquer mérito inventivo.

$\mathrm{O}$ inciso $\mathrm{V}$ estabelece que um programa de computador isolado não é considerado invenção. No entanto, ele é patenteável se estiver ligado a algum objeto. Por exemplo, é perfeitamente considerado como invenção um sistema de controle de uma caldeira (arranjo coerente de "software", válvulas de controle, dutos, etc.) realizado por computador, mas não o "software", isoladamente, que faz esse controle. A proteção legal atualmente utilizada para a proteção de "softwares" é o direito autoral. Essa proteção é decorrente do chamado direito natural que um cidadão possui e as particularidades desse tipo de proteção, bastante polêmico e controvertido por sinal, não é coberta pelas disposições da lei em estudo.

O inciso VIII diz que uma nova técnica cirúrgica não é considerada invenção, o que é bastante razoável, uma vez que assim se assegura que tais técnicas estejam ao alcance de todos os que delas possam se beneficiar. Além disso, não são considerados invenções os métodos terapêuticos e de diagnose in vivo; contudo, tais processos in vitro são considerados invenções.

Finalmente, o inciso IX assegura que os seres vivos, tal como 
são encontrados na natureza, não são considerados invenções. Por exemplo, se for isolado da terra um novo microorganismo que produza um determinado antibiótico, esse isolamento, bem como o próprio microorganismo nativo, não serão considerados invenções. Contudo, se esse mesmo microorganismo for submetido a manipulações genéticas que o tornem, por exemplo, mais potente ou mais resistente, ele será, mediante certas condições, considerado como invenção. Acredito que isso derruba o mito, defendido por alguns críticos mais radicais da nova lei de propriedade industrial, de que a soberania da Amazônia (e sua biodiversidade) estaria por ela ameaçada... Ver, também, nesse sentido, o disposto no Artigo 18, a seguir.

\section{Artigo 11}

A invenção e o modelo de utilidade são considerados novos quando não compreendidos pelo estado da técnica.

\section{Artigo 11, parágrafo $1^{\circ}$}

O estado da técnica é constituído por tudo aquilo tornado acessível ao público antes da data de depósito do pedido de patente, por descrição escrita ou oral, por uso ou qualquer outro meio, no Brasil ou no exterior, ressalvado o disposto nos Artigos 12, 16 e 17.

\section{Comentário}

O presente artigo estabelece em lei o requisito de novidade de um objeto de patente. Essa novidade é em termos absolutos, isto é, o objeto tem que ser novo no espaço e no tempo. Se alguém, em qualquer lugar ou época, tornou acessível ao público o objeto da patente pretendida, ele não será patenteável por carecer do requisito de novidade. Aqui, talvez, esteja um artigo muito importante para os pesquisadores de universidades e de centros de pesquisa: por desconhecimento da lei, acaba-se perdendo a chance de patentear algo bastante promissor comercialmente, quando se publica um artigo em revistas especializadas ou se apresenta algum trabalho em congressos ou seminários tratando do objeto pretendido. Isso é agravado mais ainda pelo modelo de avaliação de produtividade vigente, que entende que quanto mais artigos publicados e trabalhos apresentados mais produtivo é o pesquisador. Essa produtividade ${ }^{3}$, muitas vezes, facilita o acesso às linhas de financiamento governamentais para a continuidade das pesquisas. Creio, sinceramente, que tal modelo necessita ser revisto a fim de compatibilizá-lo à legislação patentária e para que os mencionados pesquisadores possam auferir os benefícios desta.

Sobre isso, permito-me um conselho: se o objeto pesquisado tiver algum interesse comercial por parte do pesquisador ou da instituição a qual ele pertence, primeiro deposite um pedido de patente correspondente e, só depois, divulgue livremente os seus detalhes!

Finalmente, recomendo fortemente que o depósito de um pedido de patente seja precedido por uma busca prévia. Tal busca pode (e deve) ser feita no INPI e em bancos de patentes no exterior acessados por computador, por meio do sistema DIALOG, por exemplo. Entretanto, qualquer busca, por melhor que seja feita, nunca é completa, haverá sempre uma parcela de documentos que não será coberta. A busca prévia tem, pois, a finalidade de minimizar os riscos envolvidos no sentido de se encontrar algum documento (patente, artigo, etc.) que invalide o requisito de novidade do objeto a ser patenteado, evitando que se perca tempo e dinheiro desnecessariamente.

\section{Artigo 12}

Não será considerada como estado da técnica a divulgação de invenção ou modelo de utilidade, quando ocorrida durante os 12 (doze) meses que precederem a data de depósito ou a da prioridade do pedido de patente, se promovida:

I pelo inventor;

II pelo Instituto Nacional da Propriedade Industrial - INPI, através de publicação do pedido de patente depositado sem o consentimento do inventor, baseado em informações deste obtidas ou em decorrência de atos por ele realizados, ou

III por terceiros, com base em informações obtidas direta ou indiretamente do inventor ou em decorrência de atos por ele realizados.

\section{Artigo 12, Parágrafo único}

O INPI poderá exigir do inventor declaração relativa à divulgação, acompanhada ou não de provas, nas condições estabelecidas em regulamento.

\section{Comentário}

O disposto no artigo acima recebe a denominação de período de graça. Recomendo fortemente que os senhores inventores não se utilizem indiscriminadamente do mecanismo previsto pelo presente Artigo 12. Ao contrário, deve-se lançar mão dele como um último recurso para se tentar salvar o requisito de novidade do objeto de um pedido de patente (e, muito comumente, de anos de pesquisa...) tornado público inadvertidamente por meio de um artigo em literatura especializada ou de exposição em um congresso, por exemplo. Por que razões?

Primeira: em tais circunstâncias, sempre haverá a possibilidade de algum questionamento legal e/ou técnico quanto à similaridade do objeto que foi tornado público previamente com relação àquele objeto do pedido correspondente, por terceiros ou pelo próprio INPI. Pode-se alegar, por exemplo, que, no pedido correspondente, está sendo introduzida matéria nova, ou mesmo que não tenha unidade inventiva (ver o Artigo 21, abaixo), com relação ao objeto divulgado previamente.

Segunda: os concorrentes (outros grupos de pesquisa ativos na área em questão, laboratórios, etc) tomarão conhecimento do estágio atual de P \& D do inventor e de seus colaboradores de forma prematura, o que pode ser estrategicamente importante para aqueles. Como assim? É simples. Se, por um lado, o artigo acima garante o monopólio dos objetos tornados públicos previamente, nada se pode fazer quanto ao monopólio dos desdobramentos técnicos não óbvios daqueles objetos. Em outras palavras, é comum que grupos de pesquisa que atuem em áreas semelhantes estejam mais ou menos no mesmo estágio de $\mathrm{P} \& \mathrm{D}$. Ao se tornar públicos determinados dados e resultados, o grupo de pesquisa concorrente salta etapas de trabalho e pode se dedicar aos esforços de $\mathbf{P} \& \mathbf{D}$ subseqüientes, tomando a dianteira na linha de estudo específica.

Terceira (e não menos importante): embora mecanismos semelhantes ao disposto no presente artigo existam na legislação de propriedade industrial de muitos países (mas não de todos os países), eles podem variar na sua forma e na sua abrangência. Nesse caso, também será aberta a possibilidade de um questionamento técnico e/ou legal quanto à similaridade do objeto tornado público previamente face ao do pedido de patente correspondente, só que no exterior, onde os custos envolvidos na burocracia envolvida podem inviabilizar esse último.

Finalmente, quando o mencionado parágrafo único diz que "O INPI poderá exigir do inventor declaração relativa à divulgação, acompanhada ou não de provas, nas condições estabelecidas em regulamento", pela minha experiência, o INPI certamente exigirá tal declaração acompanhada de tais provas, o que, no mínimo, representa um aumento dos custos envolvidos no processamento do pedido de patente correspondente, e, entre outras coisas, sujeitará o objeto do pedido a uma análise dos funcionários competentes do INPI, que podem interpretá-las de maneira desfavorável ao inventor. 
Como já dito, fiquemos, pois, do lado seguro: primeiro deposite o pedido de patente, depois divulgue o(s) seu(s) objeto(s).

\section{Artigo 13}

A invenção é dotada de atividade inventiva sempre que, para um técnico no assunto, não decorra de maneira evidente ou óbvia do estado da técnica.

\section{Comentário}

Considero esse artigo tão polêmico quanto à objetividade das palavras "evidente" e "óbvia" nele contidas. Ora, o que é evidente e óbvio para alguém bem dotado intelectualmente poderá não o ser para alguém medianamente dotado. No entanto, como os princípios por trás desse artigo já existiam na lei antiga, creio que os mecanismos usados para contornar os possíveis impasses continuem válidos.

\section{Artigo 14}

O modelo de utilidade é dotado de ato inventivo sempre que, para um técnico no assunto, não decorra de maneira comum ou vulgar do estado da técnica.

\section{Comentário}

Reproduzo, aqui, o comentário anterior, apenas substituindo as palavras "evidente" e "óbvia" por "comum" e "vulgar". No entanto, pela própria natureza do modelo de utilidade, o grau de inventividade envolvido é menor que aquele de uma invenção. Portanto, a discussão envolvendo a atividade inventiva se tornará mais acirrada e mais dificilmente defensável por parte do inventor.

Felizmente, os pedidos de patente de modelo de utilidade aplicáveis no âmbito da indústria química são muito raros.

\section{Artigo 15}

A invenção e o modelo de utilidade são considerados suscetíveis de aplicação industrial quando puderem ser utilizados ou produzidos em qualquer tipo de indústria.

\section{Comentário}

O Artigo 15 define o terceiro requisito de patenteabilidade, a aplicação industrial. Todo objeto de patente, para ser patenteável, deve servir para alguma finalidade prática. Todavia, é curioso saber que já houve casos de "inventores" que, a todo custo, quiseram patentear os chamados moto-contínuos de primeira e de segunda espécie, os quais são, respectivamente, máquinas térmicas que violam a primeira e a segunda leis da termodinâmica..

\section{SEÇÃO II: DA PRIORIDADE}

\section{Artigo 16}

Ao pedido de patente depositado em país que mantenha acordo com o Brasil, ou em organização internacional, que produza efeito de depósito nacional, será assegurado direito de prioridade, nos prazos estabelecidos no acordo, não sendo o depósito invalidado nem prejudicado por fatos ocorridos nesses prazos.

\section{Artigo 16, parágrafo $3^{\circ}$}

Se não efetuada por ocasião do depósito, a comprovação deverá ocorrer em até 180 (cento e oitenta) dias contados do depósito.

\section{Comentário}

O Artigo 16 trata de um aspecto muito importante da legislação patentária, a prioridade.

Por diversas razões, uma empresa pode ter o interesse de que o fruto de seus esforços de P \& D seja explorado comercialmente em diversos países. Daí, portanto, existe a necessidade de se requerer a patente correspondente em diferentes países de interesse.

Esse é um problema antigo, e, com o intuito de minimizar o mesmo, foi criada, há mais de cem anos, a Convenção da União de Paris (CUP), da qual o Brasil é pais signatário na qualidade de fundador. Em linhas gerais, essa convenção garante aos cidadãos de países membros e a seus cidadãos domiciliados em outro país membro que não o próprio, a chamada prioridade unionista. Por exemplo, digamos que um brasileiro depositou um pedido de patente para um dado objeto no Brasil. Pela CUP, ele terá o prazo de 1 (um) ano para depositar um pedido correspondente em qualquer país membro daquela convenção, por exemplo, a França. Se, nesse intervalo de um ano, um francês ou qualquer cidadão de um país signatário da CUP residente na França, depositar ali um pedido de patente para o mesmo objeto, esse pedido será preterido em favor do pedido do cidadão brasileiro mencionado. Ou seja, o pedido "brasileiro" teria prioridade sobre o "francês".

Além da CUP, existe o PCT (Patent Cooperation Treaty), que, entre outros aspectos, permite postergar em até trinta meses a decisão de se depositar um pedido de patente nacional (em um dado país), com base em um pedido de patente internacional previamente depositado. O Brasil também é signatário do PCT. Assim sendo, tanto a CUP quanto o PCT, se bem utilizados, serão instrumentos eficientes na tomada de decisão em questões de proteção legal de objetos em mercados externos.

\section{Artigo 16, parágrafo $5^{\circ}$}

No caso de o pedido depositado no Brasil estar fielmente contido no documento de origem, será suficiente uma declaração do depositante a este respeito para substituir a tradução simples.

\section{Comentário}

O disposto no parágrafo acima é importante no sentido de reduzir a burocracia e os custos envolvidos no depósito de pedidos de patente brasileiros reivindicando uma prioridade estrangeira. Boa parte dos custos envolvidos em tais casos se deve a tradução para o português do pedido estrangeiro. Nesse aspecto, a nova lei tráz duas inovações: a admissão de tal declaração e a aceitação de uma tradução simples. Na lei antiga, não existia a possibilidade da primeira e a segunda teria que ser juramentada, bem mais cara e menos acessível que a tradução simples.

Finalmente, esse artigo é importante também pelo fato de que, muitas vezes por questões contratuais com alguma empresa estrangeira, o pesquisador brasileiro terá que depositar o pedido correspondente ao resultado de suas pesquisas em um país estrangeiro, para, mais tarde, depositar um pedido correspondente no Brasil.

\section{Artigo 16, parágrafo $7^{\circ}$}

A falta de comprovação nos prazos estabelecidos neste artigo acarretará a perda de prioridade.

\section{Comentário}

Essa perda é irrecuperável e suas conseqüências bem podem ser avaliadas à luz dos dois comentários anteriores. 


\section{Artigo 17}

O pedido de patente de invenção ou de modelo de utilidade depositado originalmente no Brasil, sem reivindicação de prioridade e não publicado, assegurará o direito de prioridade ao pedido posterior sobre a mesma matéria depositado no Brasil pelo mesmo requerente ou sucessores, dentro do prazo de 1 (um) ano.

\section{Artigo 17, Parágrafo $1^{\circ}$}

A prioridade será admitida apenas para a matéria revelada no pedido anterior, não se estendendo à matéria nova introduzida.

\section{Artigo 17, Parágrafo $2^{\circ}$}

O pedido anterior ainda pendente será considerado definitivamente arquivado.

\section{Artigo 17, Parágrafo $3^{0}$}

O pedido de patente originário de divisão de pedido anterior não poderá servir de base de reivindicação de prioridade.

\section{Comentários}

Aqui se define em lei o que se costuma chamar de prioridade interna. No meu entender, o "caput" desse artigo é redundante, face ao que foi disposto no Artigo 16, pois, sendo o Brasil signatário da CUP, o pedido originalmente depositado, desde que não publicado, automaticamente poderia servir de base à prioridade de outro a ele correspondente no prazo de um ano.

Já o parágrafo $1^{\mathbf{0}}$ constitui uma preciosa oportunidade de se introduzir aperfeiçoamentos desenvolvidos para o objeto do pedido, após o depósito desse último. Infelizmente, a prioridade interna não protegerá os ditos aperfeiçoamentos, apenas a matéria originalmente presente no pedido. Creio que, se houvesse unidade inventiva (ver o Artigo 21, abaixo), me pareceria bastante razoável que tanto a matéria depositada originalmente quanto a introduzida posteriormente fossem beneficiadas pela prioridade interna. No entanto, é possível que os legisladores, já prevendo a polêmica que estaria envolvida na análise da dita unidade inventiva, quando da introdução da matéria nova, sabiamente fizeram a ressalva contida no parágrafo $\mathbf{1}^{\circ}$.

O parágrafo $2^{\circ}$ do presente artigo, é desnecessariamente drástico, porque ele determina o arquivamento definitivo do pedido original, o qual poderia gerar mais de um pedido de patente dentro da mesma unidade inventiva, e não apenas um como subentende-se a partir do "caput" do presente artigo.

$\mathrm{O}$ parágrafo $3^{0}$ me parece contradizer o que diz o Artigo 16, do ponto de vista da CUP; pois, se o pedido originário de divisão atender aos requisitos estipulados tanto no Artigo 16 quanto na CUP, não vejo por que motivo se deveria impedir que ele servisse de base à prioridade de outros pedidos pertinentes.

\section{SEÇÃO III: DAS INVENÇÕES E DOS MODELOS DE UTILIDADE NÃO PATENTEÁVEIS}

\section{Artigo 18}

Não são patenteáveis:

I o que for contrário à moral, aos bons costumes e à segurança, à ordem e à saúde públicas;

II as substâncias, matérias, misturas, elementos ou produtos de qualquer espécie, bem como a modificação de suas propriedades físico-químicas e os respectivos processos de obtenção ou modificação, quando resultantes de transformação do núcleo atômico; e

III o todo ou parte dos seres vivos, exceto os microorganismos transgênicos que atendam aos três requisitos de patenteabilidade
- novidade, atividade inventiva e aplicação industrial - previstos no artigo $\mathbf{8}^{\mathbf{0}}$ e que não sejam mera descoberta.

\section{Artigo 18, Parágrafo único}

Para os fins desta lei, microorganismos transgênicos são organismos, exceto o todo ou parte de plantas ou de animais, que expressem, mediante intervenção humana direta em sua composição genética, uma característica normalmente não alcançável pela espécie em condições naturais.

\section{Comentário}

Foi em torno desse artigo (e daqueles que regulam a patenteabilidade dos produtos e processos farmacêuticos e do pipeline, que veremos mais tarde) que foram travadas as lutas mais "sangrentas" sobre a nova lei de propriedade industrial. Era no artigo correspondente da antiga lei (Artigo $\mathbf{9}^{\mathbf{0}}$ ), onde estavam os produtos químicos em geral, os produtos e processos farmacêuticos e alimentícios, que se fazia a exclusão desses objetos da patenteabilidade.

Os incisos I e II acima, foram praticamente copiados da lei antiga e, sinceramente, não vejo o por quê de terem sido mantidos.

Até onde sei, nunca um pedido de patente foi indeferido com base nos preceitos dispostos no inciso I acima. Ainda à luz, desse inciso, pude ver e ler muito a respeito da (não) patenteabilidade dos produtos e processos farmacêuticos, porém não li nem vi absolutamente nada sobre a (não) patenteabilidade de armas, cuja única finalidade é ferir ou matar, ou de cigarros, por exemplo. Fatos como esses é que me convencem de que as discussões sobre a presente lei são muito mais baseadas em argumentos políticos do que em fundamentos técnicos.

Sobre o inciso II, também nada li ou ouvi, e, infelizmente, se excluiu da patenteabilidade os frutos da pesquisa na área nuclear, talvez por uma visão estreita dos nossos legisladores que vêem na manipulação do núcleo atômico somente a possibilidade de se construir armamentos, e não todo o campo da moderna diagnose médica, dos novos materiais e de tantas aplicações pacíficas que os elementos transurânicos ensejam.

Já o inciso III, no meu entender é um avanço. Nele se assegura a patenteabilidade dos microorganismos alterados geneticamente, excluindo-se aqueles nativos (tal como encontrados na natureza). Além disso, está claro que os animais e plantas (e suas partes) não são patenteáveis. Em linhas gerais, uma linhagem de células de levedura que foi alterada geneticamente para produzir mais etanol que as suas "primas" nativas é patenteável, enquanto que uma variedade de cana-de-açúcar, que foi manipulada em seus genes para ter um teor de sacarose maior que os espécimes nativos da mesma, não o é.

\section{CAPÍTULO III: DO PEDIDO DE PATENTE SEÇÃO I: DO DEPÓSITO DO PEDIDO}

\section{Artigo 19}

$\mathrm{O}$ pedido de patente, nas condições estabelecidas pelo INPI, conterá:

I requerimento;

II relatório descritivo;

III reivindicações;

IV desenhos, se for o caso;

$\mathrm{V}$ resumo; e

VI comprovante do pagamento da retribuição relativa ao depósito.

\section{Comentário}

Como toda repartição pública que se preza, o INPI cobra taxas (retribuições) sempre que possível, normalizando e formalizando os procedimentos por meio de Atos Normativos e de formulários. 
Cabe, aqui, uma palavra sobre os escritórios especializados em propriedade industrial.

Praticamente todas as exigências e providências legais estabelecidas na presente lei estão ligadas a prazos para o seu cumprimento, alguns dos quais são fatais, gerando penalizações irreversíveis. Por mais atento e sistemático que seja o pesquisador ou o empresário, é comum a não observância dos ditos prazos ou de algum aspecto formal, provocando, no mínimo, custos e atraso no processamento de seu pedido de patente. Sou da opinião que nada impede que um pedido de patente seja redigido pelo próprio inventor ou por algum membro de sua equipe, para, antes do depósito, ser analisado por um especialista em patentes. Esse último poderá fornecer algumas sugestões valiosas quanto à redação do pedido, principalmente das reivindicações, que poderão evitar muitas dores de cabeça no futuro. No entanto, a partir do depósito do pedido, considero fundamental a entrega do acompanhamento do dito processamento a um escritório especializado. Por um lado, porque eles já possuem uma estrutura de acompanhamento de prazos e de formatização, formulários próprios (e prática em preenchêlos!), contato permanente com o INPI e com colegas no exterior, entre outras ferramentas burocráticas. Por outro lado, porque essa prática vai ao encontro da tendência moderna em administração de se tercerizar serviços, a menos, é claro, que o volume de pedidos a serem depositados viabilizem um setor especificamente destinado para lidar com eles, como ocorre com muitas empresas de grande porte. Todavia, mesmo essas recorrem aos escritórios especializados, principalmente quando o pedido deverá ser depositado em outros países.

\section{SEÇÃO II: DAS CONDIÇÕES DO PEDIDO}

\section{Artigo 22}

O pedido de patente de invenção terá de se referir a uma única invenção ou a um grupo de invenções inter-relacionadas de maneira a compreenderem um único conceito inventivo.

\section{Comentário}

No que diz respeito às invenções no âmbito da química, isso quer dizer que um mesmo pedido de patente pode se referir, por exemplo, a um determinado processo químico, a(os) produto(s) desse processo, à(s) aplicação(ões) desse(s) produto(s) e a(os) seu(s) intermediário(s) e ao processo de preparação deste(s), desde que esses objetos atendam aos requisitos de patenteabilidade citados acima, compondo o que se chama de unidade inventiva, a qual já foi, inclusive, mencionada acima. Se tal unidade não existir, os objetos deverão ter a sua proteção requerida por pedidos em separado.

\section{Artigo 24}

O relatório deverá descrever clara e suficientemente o objeto, de modo a possibilitar sua realização por técnico no assunto e indicar, quando for o caso, a melhor forma de execução.

\section{Comentário}

É bom se ter sempre em mente que, em caso de litígios envolvendo questões de propriedade industrial (como nas infrações de patentes), a palavra final será dada por um juiz, a rigor, um leigo no assunto técnico atinente à patente, e em química, em particular.

Além disso, as partes envolvidas serão representadas por advogados, também leigos no dito assunto.

Portanto, o texto de um pedido de patente deverá ser claro e objetivo, e, por que não dizer, agradável de se ler.

A redação como um todo tem que ser bem criteriosa, mas, em particular, alguns cuidados também devem ser tomados no que se refere à descrição de móleculas e condições de reação, sendo indispensável a interveniência de um especialista no assunto, a fim de se evitar problemas e surpresas desagradáveis no futuro.

Sempre que possível, as moléculas, radicais, grupamentos funcionais e semelhantes devem ser nominados em conformidade com a nomenclatura da IUPAC (International Union of Pure and Applied Chemistry) de modo a se evitar qualquer tipo de "confusão" ou de ambigüidade que possibilite algum tipo de infração. Com relação a isso, recomendo o excelente trabalho dos professores Bicca e Mano sobre nomenclatura de compostos orgânicos em língua portuguesa (NOMENCLATURA DE COMPOSTOS ORGÂNICOS, Alencastro, Ricardo Bicca de, e Mano, Eloísa, Editora Guanabara, Rio de Janeiro, 1987). Com relação às grandezas físicas, elas devem ser mencionadas de acordo com o Sistema Internacional - SI.

As definições deverão ser sempre genéricas, devendo-se evitar, sempre que possível, a citação a nomes de compostos específicos ou a um valor determinado de alguma grandeza física envolvida com o objeto da patente.

Finalmente, o presente artigo também prevê a descrição do assim chamado best mode, melhor modo de concretização. Tanto quanto seja do conhecimento do inventor, o pedido de patente deverá conter o objeto descrito de modo a se obter a melhor concretização possível do mesmo.

\section{Artigo 24, Parágrafo único}

No caso de material biológico essencial à realização prática do objeto do pedido, que não possa ser descrito na forma deste artigo e que não estiver acessível ao público, o relatório será suplementado por depósito do material em instituição autorizada pelo INPI ou indicada em acordo internacional.

\section{Comentário}

Como é óbvio até para um leigo, é praticamente impossível se descrever com exatidão todas as características de um determinado microorganismo. No entanto, a Biotecnologia, mesmo aquela que não envolva os procedimentos da engenharia genética, lida, em seus processos, com variedades de microorganismos com dadas peculiaridades úteis à concretização do objeto da patente em que são empregados.

Com a finalidade de superar as barreiras descritivas que surgem na redação de um pedido de patente que envolva microorganismos, foi criado o Tratado de Budapeste, do qual, infelizmente, o Brasil não é signatário. Esse tratado estabelece algumas diretrizes e normas para o depósito de microorganismos em instituições depositárias autorizadas por ele, depósito esse que pode ser mencionado em pedidos de patente, quando necessário.

Assim, suponhamos que um inventor desenvolveu um novo processo de obtenção de insulina humana por via fermentativa, utilizando uma bactéria manipulada geneticamente. Num pedido de patente redigido sob a égide de uma lei que não contemple o depósito de microorganismos para fins de patente, uma boa parte do relatório descritivo correspondente deveria ser dedicada à descrição da bactéria em si e dos procedimentos envolvidos em sua transfecção. Por outro lado, havendo a hipótese legal de se depositar a dita bactéria em uma dada instituição, bastaria a menção do número de depósito (por exemplo ATCC 9.355, ou algo semelhante) no relatório, seguido do nome da instituição depositária e da data de depósito, para se ter uma descrição completa daquele microorganismo. Vale lembrar, que o depósito na instituição depositária deve ser feito antes do depósito do pedido correspondente na repartição de patentes.

Finalmente, cabe dizer que o parágrafo único acima, apesar de não trazer todos os benefícios que a adesão, pelo Brasil, ao Tratado de Budapeste traria, já é um avanço no que se refere às patentes na área de Biotecnologia. 


\section{Artigo 25}

As reivindicações deverão ser fundamentadas no relatório descritivo, caracterizando as particularidades do pedido e definindo, de modo claro e preciso, a matéria objeto da proteção.

\section{Comentário}

Um relatório descritivo bem redigido, por si só, não garante uma proteção eficaz ao objeto de uma patente e às suas concretizações. O que dá, efetivamente, a proteção desejada são as reivindicações de um pedido de patente. Não se pode reivindicar o que não está no relatório, mas o simples fato de um dado aspecto da invenção figurar no relatório descritivo e não nas reivindicações não significa que esse dado aspecto estará protegido; no meu entender, e com base em uma interpretação estrita da lei, não estaria. Tanto o texto legal antigo quanto o novo são bem claros nesse particular: o que define, de modo claro e preciso, a matéria objeto da proteção são as reivindicações, e não o relatório descritivo.

Costuma-se dizer que as reivindicações determinam o que os outros não podem fazer, delimitando as fronteriras do monopólio do titular da patente.

Creio que ficou claro, pelo exposto, que uma pessoa especializada em redação de patentes deverá sempre dar uma boa olhada no texto de um pedido de patente antes de seu depósito.

\section{SEÇÃO III: DO PROCESSO E DO EXAME DO PEDIDO}

\section{Artigo 30}

O pedido de patente será mantido em sigilo durante 18 (dezoito) meses contados da data de depósito ou da prioridade mais antiga, quando houver, após o que será publicado, à exceção do caso previsto no artigo 75 .

\section{Comentário}

Esse prazo de dezoito meses pode ser abreviado, mediante requerimento.

O Artigo 75 diz respeito às patentes de interesse da defesa nacional. Algo semelhante já existia na legislação antiga e, no meu entender, perdeu-se uma boa chance de se retirar tal resquício dos tempos da ditadura da lei de propriedade industrial. A lei antiga (Lei 5.772) foi promulgada em 21 de dezembro de $1971 \ldots$

\section{Artigo 30, parágrafo $2^{\circ}$}

Da publicação deverão constar dados identificadores do pedido de patente, ficando cópia do relatório descritivo, das reivindicações, do resumo e dos desenhos à disposição do público no INPI.

\section{Comentário}

Entendo que, nessa altura, cabem algumas palavras com respeito à filosofia do sistema de patentes.

Sempre procurei ver tal sistema à luz da sociedade como um todo, e não do ponto de vista de determinados setores da mesma. Se, por um lado, a patente significa um monopólio dado ao inventor, por outro, o sistema de patentes garante à sociedade o acesso a um monumental conjunto de informações técnicas, que poderá subsidiar a pesquisa e o desenvolvimento em praticamente todas as áreas do conhecimento humano. Uma pesquisa prévia a um banco de patentes, seja o do INPI, seja algum outro no exterior, permite que, em muitos casos, se evite o "reinventar da roda": um problema que um dado cientista tem hoje, pode muito bem já ter sido resolvido por outro(s) e, o que é melhor, a solução pode, inclusive, já ser de domínio público (de uso livre) se a patente correspondente já tiver sido extinta ou se houver um pedido de patente publicado no exterior, sem que tenha sido depositado no Brasil, dentro dos prazos legais cabíveis e pertinentes, um pedido de patente correspondente.

\section{Artigo 31, parágrafo único}

O exame não será iniciado antes de decorridos 60 (sessenta) dias da publicação do pedido.

\section{Comentário}

Semanalmente, o INPI edita duas revistas intituladas Revista da Propriedade Industrial - RPI, uma, de cor azul, para patentes e outra, de cor verde, para marcas. É com base na data de publicação dessas revistas, onde são publicados os despachos referentes a depósitos, publicações, pedidos de exame, concessão de cartas patente, etc., que são contados os prazos como os do artigo acima, quando não houver, no artigo correspondente, uma data de referência.

O prazo de sessenta dias dado acima permite que se prepare, em tempo hábil, as eventuais oposições, por terceiros, ao pedido ora publicado.

\section{Artigo 32}

Para melhor esclarecer ou definir o pedido de patente, o depositante poderá efetuar alterações até o requerimento do exame, desde que estas se limitem à matéria inicialmente revelada no pedido.

\section{Comentário}

Essencialmente, o disposto no presente artigo (à semelhança do artigo correspondente na antiga lei) possibilita ao requerente a realização de emendas no pedido originalmente depositado, dentro dos limites definidos em seu "caput".

Novamente, chamo a atenção com respeito à importância de uma redação bem feita de um pedido de patente. Todo ato administrativo, no decorrer do processamento de um pedido de patente, entre os quais se inclui a realização de emendas, envolve custos e postergação da concessão da respectiva cartapatente, posto que existe um prazo para a providência do dito ato. Um pedido de patente bem redigido, pouco provavelmente demandará a realização de emendas em suas partes constituintes e terá o seu processamento decorrido com menos custos e mais rapidamente.

Por outro lado, a possibilidade de se realizar emendas materializa a chance de se inserir matéria que ajude a fortalecer a descrição e a concretização do objeto de um pedido de patente. No caso específico das patentes químicas, tem-se a possibilidade de se incluir, por exemplo, novos exemplos de síntese de moléculas, englobadas por uma fórmula geral comum ali reivindicada, que, por questões de tempo, não puderam ser incluídos no pedido originalmente depositado. Além disso, tem-se a oportunidade de incluir ajustes finos em condições de reação, de especificação de equipamentos, de definição de grupos funcionais, etc.

Nesse sentido, ver o disposto no Artigo 76, mais adiante.

\section{Artigo 33}

O exame do pedido de patente deverá ser requerido pelo depositante ou por qualquer interessado, no prazo de 36 (trinta e seis) meses contados da data do depósito, sob pena do arquivamento do pedido. 


\section{Comentário}

Praticamente nada é automático, em termos de providências que favoreçam o requerente de um pedido de patente, na lei em estudo. Portanto, é necessário um constante acompanhamento, pela leitura da RPI correspondente, das publicações de interesse. Se esse prazo de requerimento de exame for perdido, o desarquivamento poderá ser solicitado, por outro requerimento (acompanhado da retribuição devida...).

\section{Artigo 35}

Por ocasião do exame técnico, será elaborado o relatório de busca e parecer relativo a:

I patenteabilidade do pedido;

II adaptação do pedido à natureza reivindicada;

III reformulação do pedido ou divisão; ou

IV exigências técnicas.

\section{Comentário}

O presente artigo e os demais a ele relacionados, bem como os seus correspondentes na antiga lei, consubstanciam a figura do exame técnico do pedido de patente.

Sem dúvida, uma das figuras mais polêmicas dentro do INPI é o examinador de patentes.

É fato que as condições de trabalho desses funcionários públicos estão longe de ser as ideais: baixos salários, falta de treinamentos de reciclagem, baixo índice de informatização da burocracia dentro do INPI, número enorme de pedidos a serem examinados por cada examinador são apenas alguns dos fatores que favorecem a prestação de um serviço aquém do esperado pela sociedade. No entanto, determinadas posturas eminentemente políticas daqueles funcionários vieram a dificultar e retardar bastante o processamento de pedidos de patente nas áreas de química (composições) e de Biotecnologia (processos envolvendo microorganismos) até o advento da nova lei.

Além disso, algumas exigências "técnicas" formuladas por alguns examinadores do INPI demonstram, nos casos extremos, sinais de incompetência, no mínimo.

Pela lei antiga, os litígios mais sérios sem uma decisão de consenso, durante a fase administrativa, tinham a sua instância mais alta na figura do Ministro de Estado da Indústria e do Comércio (ministério ao qual o INPI era subordinado; atualmente, ele está sob a jurisdição do Ministério da Justiça). Pela nova lei, contudo, a instância mais alta da esfera administrativa, em tais casos, é o Presidente do INPI. Esperemos que o corporativismo não seja um fator relevante na decisão dos eventuais litígios futuros e, além disso, sempre há o Supremo Tribunal Federal para dar a palavra final.

\section{Artigo 36}

Quando o parecer for pela não patenteabilidade ou pelo não enquadramento do pedido na natureza reivindicada ou formular qualquer exigência, o depositante será intimado para manifestar-se no prazo de 90 (noventa) dias.

\section{Artigo 36, parágrafo $1^{0}$}

Não respondida a exigência, o pedido será definitivamente arquivado.

\section{Comentário}

Jamais uma exigência deverá deixar de ser respondida. Por mais absurda e pueril que ela seja, sempre deverá haver uma resposta, não necessariamente, é claro, um cumprimento cego à mesma. Quando atuei como analista de patentes, presenciei diversos casos em que exigências foram contestadas, com base em argumentos técnicos galgados na lógica e no bom senso, e essa contestação foi aceita pelos examinadores do INPI.

\section{CAPÍTULO IV: DA CONCESSÃO E DA VIGÊNCIA DA PATENTE SEÇÃO I: DA CONCESSÃO DA PATENTE}

\section{Artigo 38, parágrafo $1^{\circ}$}

O pagamento da retribuição e respectiva comprovação deverão ser efetuados no prazo de 60 (sessenta) dias contados do deferimento.

\section{Comentário}

Existe aqui uma sutileza que, muitas vezes, não é observada: não basta apenas pagar a retribuição necessária, é preciso comprovar esse pagamento para que a carta-patente seja expedida. Essa comprovação é feita por meio de formulário próprio a ser apresentado ao INPI dentro do prazo estipulado. Caso não sejam feitos o pagamento e a respectiva comprovação no prazo acima, começa a correr outro, de 30 (trinta) dias, para que tais providências sejam tomadas. Se, ainda assim, elas não forem cumpridas, o arquivamento do pedido será definitivo.

\section{SEÇÃO II: DA VIGÊNCIA DA PATENTE}

\section{Artigo 40}

A patente de invenção vigorará pelo prazo de 20 (vinte) anos e a de modelo de utilidade pelo prazo de 15 (quinze) anos contado da data do depósito.

\section{Comentário}

Pela lei antiga, esses prazos eram de 15 e de 10 anos, respectivamente.

\section{CAPÍTULO V: DA PROTEÇÃO CONFERIDA PELA PATENTE SEÇÃO I: DOS DIREITOS}

\section{Artigo 41}

A extensão da proteção conferida pela patente será determinada pelo teor das reivindicações, interpretado com base no relatório descritivo e nos desenhos.

\section{Artigo 42}

A patente confere ao seu titular o direito de impedir terceiro, sem o seu consentimento, de produzir, usar, colocar à venda, vender ou importar com estes propósitos:

I produto objeto da patente;

II processo ou produto obtido diretamente por processo patenteado.

\section{Comentário}

Conforme já foi dito, reivindicações é sinônimo de direito. Esse direito se materializa na posse de um bem móvel, no caso a invenção, que pode ser disposto, pelo titular do direito, da maneira que lhe aprouver.

A legislação antiga não assegurava patente a qualquer tipo de produto químico. No entanto, os produtos novos, preparados por processos também novos, recebiam um tipo especial de proteção chamado product-by-process protection. Por ele, o produto ficava protegido pela patente do respectivo processo de preparação. No entanto, isso era apenas um princípio normalmente 
aceito, nada havendo na letra da antiga lei nesse sentido. O inciso II, portanto, vem modificar esse quadro.

\section{Artigo 42, parágrafo $2^{\circ}$}

Ocorrerá a violação de direito de patente de processo, a que se refere o inciso II, quando o possuidor ou proprietário não comprovar, mediante determinação judicial específica, que o seu produto foi obtido por processo de fabricação diverso daquele protegido pela patente.

\section{Artigo 43}

O disposto no artigo anterior não se aplica:

(...)

II aos atos praticados por terceiros não autorizados, com finalidade experimental, relacionados a estudos ou pesquisas científicas ou tecnológicas;

III à preparação de medicamentos de acordo com prescrição médica para casos individuais, executada por profissional habilitado, bem como ao medicamento assim preparado; (...)

\section{Comentário}

O parágrafo $2^{\circ}$ do Artigo 42 é muito interessante do ponto de vista legal. Ele traz em si um instituto jurídico conhecido como reversão do ônus da prova.

Quando se suspeita de que alguém cometeu um furto, por exemplo, não se pode acusá-lo, a menos que se disponha de provas ou de evidências nesse sentido.

No caso de uma infração de patente, principalmente daquelas envolvendo um processo químico, embora não seja impossível, é relativamente difícil de se obter provas que indiquem tal ilícito. Prevendo isso, os legisladores da nova lei foram bastante sábios ao estabelecerem que o acusado de infração é quem deve provar que não está em delito. Contudo, é bom se ter cuidado em não ser leviano a ponto de se acusar alguém sem fortes indícios para tal, o que, inclusive, pode ensejar, por parte do acusado, ações judiciais por difamação e calúnia, no mínimo.

O que fazer, então? No caso específico de infração de patente de processo químico, não é muito difícil se obter os indícios necessários para uma acusação. Normalmente, um produto químico traz consigo algumas características do processo que o produziu (algum resíduo ou impureza, ligado a dada particularidade de uma certa etapa de sua síntese). Assim, uma análise cuidadosa de amostras do produto suspeito (obtidas, por exemplo, no comércio), feita, de preferência, por alguma instituição independente, pode revelar tais indícios.

Finalmente, chamo a atenção às exceções nos incisos do Artigo 43; os relevantes para as atividades de P \& D foram por mim reproduzidos aqui.

\section{Artigo 44}

Ao titular da patente é assegurado o direito de obter indenização pela exploração indevida de seu objeto, inclusive em relação à exploração ocorrida entre a data da publicação do pedido e a da concessão da patente.

\section{Artigo 44, parágrafo $1^{\circ}$}

Se o infrator obteve, por qualquer meio, conhecimento do pedido depositado, anteriormente à publicação, contar-se-á o período de exploração indevida para efeito da indenização a partir da data de início da exploração.

\section{Comentário}

Como cidadão brasileiro, sei que a Justiça aqui é, as vezes, algo difícil de ser conseguido. No entanto, Justiça não é chuva: ela não cai do céu; é preciso lutar por ela. Nos meus anos de atividade como analista de patentes em um grande escritório de propriedade industrial, pude testemunhar o trabalho de diversos colegas, advogados, em atividades de busca e de apreensão envolvendo litígios sobre marcas e patentes, muitos dos quais foram vitoriosos e, efetivamente, fizeram cumprir a lei.

Além disso, chamo a atenção para um aspecto legal conhecido como expectativa de direito. Ao se depositar um pedido de patente, não se obtém, automaticamente, a proteção para o objeto em questão. Essa proteção só será conseguida quando da expedição da dita carta-patente (do documento, em si). No entanto, o disposto no presente artigo prevê o ressarcimento, decorrente da exploração não autorizada e dolosa, mesmo antes da concessão da dita carta.

\section{SEÇÃO II: DO USUÁRIO ANTERIOR}

\section{Artigo 45}

À pessoa de boa fé que, antes da data de depósito ou de prioridade de pedido de patente, explorava seu objeto no país, será assegurado o direito de continuar a exploração, sem ônus, na forma e condição anteriores.

\section{Comentário}

Esse é, sem dúvida, um artigo sábio, pois tais casos de boafé ocorrem de fato. No entanto, como se poderá provar essa boa-fé é algo que considero tarefa muito complicada, na prática.

\section{CAPÍTULO VI: DA NULIDADE DA PATENTE SEÇÃO I: DAS DISPOSIÇÕES GERAIS}

\section{Artigo 46}

É nula a patente concedida contrariando as disposições dessa lei.

\section{Comentário}

Quando se diz disposições no artigo acima, essa palavra deve ser entendida da forma mais ampla possível, e não apenas no que diz respeito, como normalmente se intui, à patenteabilidade. Não apenas os aspectos técnicos atinentes a uma patente, que servem de base a eventuais oposições a um pedido, devem ser observados, mas também aqueles ligados à burocracia propriamente dita do seu processamento. Um especialista em patentes que seja hábil e atento, estará sempre pronto a observar e a cumprir tempestivamente os prazos estipulados na lei, evitando que terceiros se aproveitem desse fato. Já houve um caso, ainda na vigência da antiga lei, em que um pedido de patente, depositado por certa empresa, foi anulado porque não foi cumprido um determinado prazo legal de seu processamento. Curiosamente, ninguém se deu conta desse descuido, nem no INPI, menos um advogado de um escritório representando outra empresa interessada em anular aquele pedido...

\section{Artigo 47}

A nulidade poderá não incidir sobre todas as reivindicações, sendo condição para a nulidade parcial o fato de as reivindicações subsistentes constituirem matéria patenteável por si mesmas.

\section{Comentário}

Isso me parece óbvio, uma vez que os direitos do titular são normalmente estabelecidos por mais de uma reivindicação. No caso de um pedido de patente, cujos objetos são um processo de preparação de dado produto, esse produto e sua aplicação para alguma finalidade, poderá haver a anulação somente das 
reivindicações referentes ao produto, se algum terceiro puder provar que ele não atende aos requisitos de patenteabilidade mencionados anteriormente, mantendo-se as demais em vigor.

\section{Artigo 48}

A nulidade da patente produzirá efeitos a partir da data do depósito do pedido.

\section{Comentário}

Uma patente (ou pedido de patente) anulada (anulado) gera os mesmos efeitos que seriam observados se ela (ele) nunca tivesse existido. Voltemos aos meus comentários a respeito do Artigo 16, parágrafo $3^{\circ}$. Se o pedido de patente "brasileiro" fosse anulado por alguma razão, seria como se ele jamais tivesse existido. Nesse caso, o pedido "francês" seria o pedido prioritário. Esse é apenas um exemplo específico que se refere à prioridade do pedido de patente. Outras implicações ocorreriam, mutatis mutandi, com relação a outros aspectos e conceitos da legislação, em decorrência da nulidade.

\section{SEÇÃO III: DA AÇÃO DE NULIDADE}

\section{Artigo 56}

A ação de nulidade poderá ser proposta a qualquer tempo da vigência da patente, pelo INPI, ou por qualquer pessoa com legítimo interesse.

\section{Comentário}

A concessão da carta-patente não é irrevogável. A lei é clara: sempre é tempo, durante a vigência da patente, para se requerer a sua nulidade, se houver razões para tal. O próprio INPI poderá fazer isso, se julgar correto. Apesar disso, o titular da patente anulada terá um prazo de 60 (sessenta) dias para apresentar os seus argumentos de defesa.

\section{CAPÍTULO VIII: DAS LICENÇAS SEÇÃO I: DA LICENÇA VOLUNTÁRIA}

\section{Artigo 61}

O titular da patente ou o depositante poderá celebrar contrato de licença para exploração.

\section{Comentário}

Isso é uma das possibilidades que a posse de um dado bem móvel permite ao seu titular.

\section{Artigo 62}

O contrato de licença deverá ser averbado no INPI para que produza efeitos em relação a terceiros.

\section{Comentário}

Sinceramente, considero que, aqui, houve uma extrapolação das atribuições do INPI. Primeiro, porque o INPI já não tem condições para fazer eficientemente aquilo para o qual foi criado: processar pedidos de patente e de registro de marcas e emitir os diplomas legais correspondentes. Na vigência da lei antiga, na qual essa averbação foi estabelecida por força de Ato Normativo, o INPI se mostrou muito lento para analisar os contratos de licença que a ele foram apresentados. Segundo, se está burocratizando, por meio da ingerência de uma autarquia federal, algo que, a rigor, não depende dessa autarquia para existir: a licença pressupõe um contrato, o qual define um acordo entre as partes envolvidas, e apenas entre elas. Ora, se o contrato contiver cláusulas que contrariem a lei, seja ela qual for (penal, cível, de propriedade industrial, etc.) ele não terá valor legal e, se não as tiver, será perfeitamente válido.

\section{SEÇÃO II: DA OFERTA DE LICENÇA}

\section{Artigo 64}

O titular da patente poderá solicitar ao INPI que a coloque em oferta para fins de exploração.

\section{Artigo 66}

A patente em oferta terá sua anuidade reduzida à metade no período compreendido entre o oferecimento e a concessão da primeira licença, a qualquer título.

\section{Comentário}

Esses artigos introduzem matéria nova com relação à lei anterior. Creio que aqui exista algo muito interessante para as entidades que lidam com P \& D, nos moldes das instituições universitárias governamentais. Caso não haja interesse em se explorar comercialmente os objetos da patente, a mesma poderia ser ofertada à licença, por meio do INPI, para que fosse explorada por alguma empresa interessada. Apesar de não parecer muito atraente do ponto de vista econômico, as implicações sociais desses fatos são muito grandes. Digamos que algum centro de pesquisa universitário desenvolva um novo medicamento contra a malária. Por razões estatutárias, poderia haver o impedimento da exploração comercial desse objeto por parte daquela instituição, porém a sua patente poderia ser oferecida, por meio de uma licença, a algum laboratório que se dispusesse a produzí-la, sob determinadas condições.

\section{Artigo 67}

O titular da patente poderá requerer o cancelamento da licença se o licenciado não der início à exploração efetiva dentro de 1 (um) ano da concessão, interromper a exploração por prazo superior a 1 (um) ano, ou, ainda se não forem obedecidas as condições para a exploração.

\section{Comentário}

Manteve-se aqui um dispositivo que já existia na lei anterior, qual seja o de obrigar o cessionário a explorar o objeto da patente licenciada, dentro de um determinado período, sob pena do cancelamento da licença. Parece-me justo que, se alguém se dispuser a obter uma licença de exploração de uma patente, é para explorá-la efetivamente.

\section{SEÇÃO III: DA LICENÇA COMPULSÓRIA}

\section{Artigo 68}

O titular ficará sujeito a ter a patente licenciada compulsoriamente se exercer os direitos dela decorrentes de forma abusiva, ou por meio dela praticar abuso de poder econômico, comprovado nos termos da lei, por decisão administrativa ou judicial.

\section{Artigo 68, parágrafo $1^{\circ}$}

Ensejam, igualmente, licença compulsória:

I a não exploração do objeto da patente no território brasileiro por falta de fabricação ou fabricação incompleta do produto, ou, ainda, a falta de uso integral do processo patenteado, 
ressalvados os casos de inviabilidade econômica, quando será admitida a importação: ou

II a comercialização que não satisfizer à necessidades do mercado.

\section{Artigo 68, parágrafo $5^{\circ}$}

A licença compulsória de que trata o parágrafo $1^{\circ}$ somente será requerida após decorridos 3 (três) anos da concessão da patente.

\section{Comentário}

Como se pode ver, a nova lei de propriedade industrial tem mecanismos bastante claros e eficazes para combater os abusos ligados ao poder econômico perpetrados pelo titular de uma patente, inclusive com a perda do monopólio conferido pela mesma (com relação a esse artigo, veja a discussão intitulada "O SISTEMA DE PATENTES E A INDÚSTRIA FARMACÊUTICA", no final do presente trabalho).

Chamo, ainda, a atenção para o prazo de três anos para o início da exploração efetiva do objeto da patente, sob pena de se requerer a sua licença compulsória.

\section{Artigo 69}

A licença compulsória não será concedida se, à data do requerimento, o titular:

I justificar o desuso por razões legítimas;

II comprovar a realização de sérios e efetivos preparativos para a exploração; ou

III justificar a falta de fabricação ou comercialização por obstáculo de ordem legal.

\section{Comentário}

Toda lei sábia tem as suas contrapartidas e compensações. É possível que, por alguma razão justificável, ocorram atrasos na exploração do objeto de uma patente. Não creio que seja uma tarefa muito difícil para os nossos magistrados diferenciar o joio do trigo.

\section{Artigo 72}

As licenças compulsórias serão sempre concedidas sem exclusividade, não se admitindo o sublicenciamento.

\section{Comentário}

Não seria razoável coibir um abuso com outro abuso. Claro está que devem ser concedidas tantas licenças quantas forem necessárias para se garantir o abastecimento do mercado da forma a mais completa possível.

\section{Artigo 72, parágrafo $\mathbf{2}^{\circ}$}

O requerente de licença que invocar abuso de direitos patentários ou abuso de poder econômico deverá juntar documentação que o comprove.

\section{Comentário}

Aqui não há o aspecto legal da reversão do ônus da prova. No entanto, parece não ser muito descabida a hipótese de que a documentação de que trata o artigo acima não seja muito difícil de se obter, uma vez que ela se baseia, ou pode se basear, em dados de mercado, de importações, de consumo, de vendas, etc., de acesso bem menos restrito que aqueles encerrados nas instalações industriais de uma empresa infratora de uma patente.

\section{Artigo 74}

Salvo razões legítimas, o licenciado deverá iniciar a exploração do objeto da patente no prazo de 1 (um) ano da concessão da licença, admitida a interrupção por igual prazo.

\section{Comentário}

Valem, aqui, os meus comentários feitos com relação ao Artigo 67, acima.

\section{Artigo 74, paragráfo $1^{\circ}$}

O titular poderá requerer a cassação da licença quando não cumprido o disposto neste artigo.

\section{Comentário}

Esse artigo vem impedir que a licença da patente se transforme em licença para novo abuso. Quem requerer uma licença compulsória e a obtiver tem a obrigação de não cometer os mesmos erros que aquele a quem a licença é reclamada, sob pena de perdê-la.

\section{Artigo 74, paragráfo $2^{\circ}$}

O licenciado ficará investido de todos os poderes para agir em defesa da patente.

\section{Comentário}

Tenha-se em mente que não ocorre mudança de titularidade quando uma licença é concedida: essa ainda pertence a quem licencia a patente. O licenciado, contudo, passa a ter o direito de explorar comercialmente (vender, bem entendido) o objeto da patente.

\section{CAPÍTULO X: DO CERTIFICADO DE ADIÇÃO DE INVENÇÃO}

\section{Artigo 76}

O depositante do pedido ou titular da patente de invenção poderá requerer, mediante pagamento de retribuição específica, certificado de adição para proteger aperfeiçoamento ou desenvolvimento introduzido no objeto da invenção, mesmo que destituído de atividade inventiva, desde que a matéria se inclua no mesmo conceito inventivo.

\section{Comentário}

Os senhores pesquisadores bem sabem que é muito comum, no decorrer de um trabalho de pesquisa, que novos fatos surjam apontando aperfeiçoamentos e modificações no objeto pesquisado. Um exemplo deve ajudar: seja um pedido de patente que foi depositado com a finalidade de proteger um dado processo químico novo. Digamos que, após o depósito, o inventor constate que uma dada etapa do tal processo poderia incluir um determinado auxiliar de reação que propiciaria um aumento ponderável no seu rendimento. O Artigo 76 permite que, por meio do mencionado certificado de adição, seja incluído esse melhoramento no objeto do pedido de patente.

\section{CAPÍTULO XI: DA EXTINÇÃO DA PATENTE}

\section{Artigo 78}

A patente extingui-se:

I pela expiração do prazo de vigência; 
II pela renúncia de seu titular, ressalvado o direito de terceiros; III pela caducidade;

IV pela falta de pagamento de retribuição anual, nos prazos previstos no parágrafo $2^{\circ}$ do artigo 84 e no artigo 87; e

$\mathrm{V}$ pela inobservância do disposto no artigo 217.

\section{Comentário}

Primeiramente, gostaria de ressaltar a diferença entre nulidade e caducidade. A nulidade, como já foi dito, gera os mesmos efeitos que aqueles que resultariam se o pedido de patente ou a patente não existisse (a data de depósito de um pedido anulado não pode servir como prioridade para outro pedido). Já a caducidade interrompe a patente (não há caducidade de pedido) mas não extingüe os fatos decorrentes da existência da patente (a data de depósito de um pedido caducado pode servir como prioridade para outro pedido).

$\mathrm{O}$ objeto de uma patente que tenha sido extinta cai em domínio público: qualquer pessoa pode explorá-lo livremente.

$\mathrm{O}$ inciso I é óbvio.

Quanto ao inciso II, foi feita a importante ressalva que protege um terceiro que, por exemplo, tenha obtido uma licença para explorar o objeto da patente ameaçada de extinção.

Sobre a caducidade, falaremos mais, logo a seguir.

$\mathrm{O}$ inciso IV se refere às anuidades que devem ser pagas anualmente, durante a vigência da patente. Lembre-se: o não pagamento da anuidade nos prazos previstos pela lei pode provocar, em caso extremo, a caducidade da patente.

$\mathrm{O}$ inciso $\mathrm{V}$ diz respeito à obrigatoriedade dos titulares de pedidos de patente residentes no exterior de manter, no Brasil, um procurador qualificado e domiciliado em nosso país.

\section{Artigo 80}

Caducará a patente, de ofício ou a requerimento de qualquer pessoa com legítimo interesse, se, decorridos 2 (dois) anos da concessão da primeira licença compulsória, esse prazo não tiver sido suficiente para prevenir ou sanar o abuso ou desuso, salvo motivos justificáveis.

\section{Comentário}

No meu entender, esse artigo dá o tiro de misericórdia nos argumentos daqueles que pregam que a lei sobre patentes só serve aos interesses do poder econômico em detrimento da sociedade. Concordo que decisões judiciais envolvendo questões desse tipo podem demorar algum tempo, porém a lei, em si, tem mecanismos claros e eficazes para coibir abusos e impedir a submissão da sociedade ao poder econômico, inclusive, como já foi visto, retroativamente.

A expressão de ofício é sinônima de por iniciativa do INPI.

\section{Artigo 80, parágrafo $1^{\circ}$}

A patente caducará quando, na data do requerimento da caducidade ou da instauração de ofício do respectivo processo, não tiver sido iniciada a exploração.

\section{Comentário}

A lei pressupõe que quem requer um pedido de patente pretende explorar o objeto da mesma. Caso contrário, para que se conceder uma patente a alguém que não pretende explorá-la? A lei é igualmente sábia, nesse aspecto, ao garantir a manutenção do monopólio concedido pela patente somente para aqueles que pretendam, efetivamente, explorá-la de modo a ofertar esse objeto à sociedade.

Além disso, esse artigo evita a especulação com tecnologia: a patente é um bem móvel que pode ter seu valor alterado de acordo com a conjuntura do mercado. Não me parece justo que a sociedade fique privada de um avanço tecnológico, que poderia representar uma melhoria da qualidade de vida dos indivíduos dessa sociedade, por razões de usura.

\section{Artigo 80, parágrafo $2^{\circ}$}

No processo de caducidade instaurado a requerimento, o INPI poderá prosseguir se houver desistência do requerente.

\section{Comentário}

Outro artigo importante. Ele pode dificultar "acordos" entre o requerente da caducidade e o titular da patente no sentido de perpetuar o abuso com favorecimento de ambos, em detrimento da sociedade.

\section{CAPÍTULO XII: DA RETRIBUIÇÃO ANUAL}

\section{Artigo 84}

O depositante do pedido e o titular da patente estão sujeitos ao pagamento de retribuição anual, a partir do início do terceiro ano da data do depósito.

\section{Comentário}

Os legisladores tiveram a sensibilidade de reconhecer que o processo de concessão de uma carta-patente não é barato. Assim, fixaram, em lei, que as anuidades deverão ser pagas só a partir do terceiro ano a contar do depósito e, implicitamente, também reconheceram que o prazo ideal para a concessão da dita carta é de três anos... Atualmente, o prazo médio para a concessão da carta-patente para os pedidos de patente químicos "normais" é de 5 a 6 anos.

\section{Artigo 86}

A falta de pagamento da retribuição anual, nos termos dos artigos 84 e 85 , acarretará o arquivamento do pedido ou a extinção da patente.

\section{Comentário}

Já comentei esse fato quando da apresentação do Artigo 78, acima.

\section{CAPÍTULO XIV: DA INVENÇÃO E DO MODELO DE UTILIDADE REALIZADO POR EMPREGADO OU PRESTADOR DE SERVIÇO}

\section{Artigo 88}

A invenção e o modelo de utilidade pertencem exclusivamente ao empregador quando decorrerem de contrato de trabalho cuja execução ocorra no Brasil e que tenha por objeto a pesquisa ou a atividade inventiva, ou resulte esta da natureza dos serviços para os quais foi o empregado contratado.

\section{Comentário}

Isso quer dizer que a titularidade da invenção de um empregado pertence ao empregador se este tiver contratado aquele com a finalidade de inventar. Isso, no entanto, ocorre quando não houver nada estipulado no contrato de trabalho firmado entre ambos nesse sentido. Nada impede, todavia, que possa se obter uma situação diferente, se existirem cláusulas naquele contrato ou nos estatutos da instituição a que pertença o inventor, que estabeleçam uma partilha diferente dos direitos de propriedade industrial entre empregador e empregado. A propósito: o leitor 
conhece os estatutos da instituição a que pertence que tratam dessa matéria? E o seu contrato de trabalho, o que diz a respeito?

\section{Artigo 90}

Pertencerá exclusivamente ao empregado a invenção ou o modelo de utilidade por ele desenvolvido, desde que desvinculado do contrato de trabalho e não decorrente da utilização de recursos, meios, dados, materiais, instalações ou equipamentos do empregador.

\section{Comentário}

Digamos que um químico, empregado de um centro de pesquisas na área de química fina, que goste muito de eletrônica, desenvolveu um aperfeiçoamento para um colorímetro. No seu dia-a-dia, esse empregado trabalha com sínteses orgânicas. Nesse caso, a lei assegura, a esse empregado, a titularidade da patente de modelo de utilidade para esse colorímetro aperfeiçoado, caso ele queira requerer tal patente.

\section{Artigo 91}

A propriedade de invenção ou de modelo de utilidade será comum, em partes iguais, quando resultar da contribuição pessoal do empregado e de recursos, dados, meios, materiais, instalações ou equipamentos do empregador, ressalvada expressa disposição contratual em contrário.

\section{Comentário}

Digamos que o empregado do comentário anterior, ao invés de por eletrônica, fosse um aficcionado por mecânica. Suponhamos, ainda, que, no desenvolvimento de uma dada síntese orgânica, ele, paralelamente, projetou um reator especial que se adapta excepcionalmente bem a uma síntese específica. Nesse caso, apesar de não ser um objeto diretamente ligado a atividade de inventor para qual ele foi contratado, ele está indiretamente ligado a ela e, certamente, houve o uso de recursos, dados, meios, materiais, instalações ou equipamentos do empregador. O presente artigo visa a dirimir quaisquer dúvidas suscitadas em tais casos.

\section{Artigo 91, parágrafo $3^{\circ}$}

A exploração do objeto da patente, na falta de acordo, deverá ser iniciada pelo empregador dentro do prazo de 1 (um) ano, contado da data de sua concessão, sob pena de passar à exclusiva propriedade do empregado a titularidade da patente, ressalvadas as hipóteses de falta de exploração por razões legítimas.

\section{Comentário}

Com as devidas alterações, é, aqui, ressalvado o interesse da sociedade de se garantir a exploração da patente a quem se dispuser a explorá-la de maneira idônea.

\section{Artigo 93, parágrafo único}

Na hipótese do artigo 88, será assegurada ao inventor, na forma e condições previstas no estatuto ou regimento interno da entidade a que se refere esse artigo, premiação de parcela no valor das vantagens auferidas com o pedido ou com a patente, a título de incentivo.

\section{Comentário}

No meu entender, esse artigo é totalmente inútil. Por um lado, se houver a previsão regimental de algum tipo de benefício ao inventor, por parte da instituição a que ele pertença, esse artigo transferirá a definição dos termos desse benefício para o dito regimento interno. Se não houver aquela previsão, ele será inócuo. Melhor teria sido se tivesse sido omitida a expressão na forma e condições previstas no estatuto ou regimento interno da entidade a que se refere esse artigo, substituindo-a por outra que melhor definisse os termos da dita premiação.

\section{TÍTULO VIII: DAS DISPOSIÇÕES TRANSITÓRIAS E FINAIS}

\section{Artigo 229}

Aos pedidos em andamento serão aplicadas as disposições desta lei, exceto quanto à patenteabilidade das substâncias, matérias ou produtos obtidos por meios ou processos químicos e as substâncias, matérias, misturas ou produtos alimentícios, químico farmacêuticos e medicamentos de qualquer espécie, bem como os respectivos processos de obtenção, que só serão privilegiáveis nas condições estabelecidas nos artigos 230 e 231.

\section{Comentário}

Sempre que existe a mudança de uma lei vigente para outra que a substitui, é necessário se definir a situação dos casos pendentes ou em andamento, a fim de que haja continuidade no sistema legal envolvido. No meu entender, seria muito mais razoável que as disposições da nova lei fossem estendidas aos pedidos em andamento de qualquer natureza, por duas razões. Primeiro, porque se premiaria quem apostou no Brasil, depositando (no advento da lei antiga) pedidos de patente para, por exemplo, fármacos novos. Depositar um pedido de patente sob a validade da lei antiga significava o risco de perder todo o dinheiro investido para essa finalidade, se a nova lei mantivesse a não patenteabilidade para aqueles objetos. Segundo, porque se evitaria a aberração do pipeline, sobre o qual falarei a seguir.

\section{Artigo 230}

Poderá ser depositado pedido de patente relativo às substâncias, matérias ou produtos obtidos por meios ou processos químicos e às substâncias, matérias, misturas ou produtos alimentícios, químico farmacêuticos e medicamentos de qualquer espécie, bem como os respectivos processos de obtenção ou modificação, por quem tenha proteção garantida em tratado ou convenção em vigor no Brasil, ficando assegurada a data do primeiro depósito no exterior, desde que seu objeto não tenha sido colocado em qualquer mercado, por iniciativa direta do titular ou por terceiro com seu consentimento, nem tenham sido realizados, por terceiros, no País, sérios e efetivos preparativos para a exploração do objeto do pedido ou da patente.

\section{Artigo 231}

Poderá ser depositado pedido de patente relativo às matérias de que trata o artigo anterior, por nacional ou pessoa domiciliada no País, ficando assegurada a data de divulgação do invento, desde que seu objeto não tenha sido colocado em qualquer mercado, por iniciativa direta do titular ou por terceiro com seu consentimento, nem tenham sido realizados, por terceiros, no País, sérios e efetivos preparativos para a exploração do objeto do pedido.

\section{Artigo 232}

A produção ou utilização, nos termos da legislação anterior, de substâncias, matérias ou produtos obtidos por meios ou processos químicos e de substâncias, matérias, misturas ou produtos alimentícios, químico farmacêuticos e medicamentos de 
qualquer espécie, bem como os respectivos processos de obtenção ou modificação, mesmo que protegidos por patente de produto ou processo em outro país, de conformidade com tratado ou convenção em vigor no Brasil, poderão continuar, nas mesmas condições anteriores à aprovação desta lei.

\section{Comentário}

Os três artigos anteriores definem o que se denomina pipeline.

Existe um princípio elementar do Direito Internacional chamado reciprocidade. Em linhas gerais, ele estabelece que, na ocasião de um tratado entre dois ou mais países, são assegurados, aos cidadãos dos países contratantes, os mesmos direitos. Ora, no meu entender, o pipeline só seria aceitável se também fosse introduzido um dispositivo semelhante a ele nas legislações de propriedade industrial dos países que venham a requerer pedidos de patente para seus objetos invocando o pipeline.

Acredito que houve um enorme cochilo de nossos legisladores ao se introduzir esse dispositivo na nova lei de propriedade industrial brasileira. Talvez, no afã de se dar alguma compensação à indústria farmacêutica pela demora do governo brasileiro em se conceder patentes a medicamentos e a seus processos de obtenção, esse mecanismo tenha sido ali introduzido.

Não estou a par dos termos do General Agreement on Trade and Tariff (GATT) no que se refere à propriedade industrial. Mesmo assim, ouso afirmar que não há nada ali que obrigasse o Brasil a adotar algo como o pipeline em sua legislação.

$\mathrm{O}$ teor do pipeline contradiz o requisito de patenteabilidade da novidade, além de se gerar um certo mal estar pela existência de um dispostivo dessa natureza.

Contudo, creio que o pipeline não devia ter sido objeto de preocupação ou mesmo de consideração pelo pesquisador e industrial brasileiros, por duas razões. A primeira, se prende ao fato de que ele está compreendido no título das disposições transitórias da nova lei e, como tudo que é transitório, tinha prazo determinado para terminar, no caso 1 (um) ano a contar da publicação da mesma, ou seja, 13.05.96. Segundo, porque a taxa envolvida, cobrada pelo INPI, no depósito dos pedidos pipeline era muito mais elevada que aquelas cobradas referentes aos pedidos normais. Só para se ter uma idéia, essa taxa referente aos pedidos normais é de $\mathbf{R} \$ \mathbf{1 0 9 , 0 0}$ e aquela referente aos pedidos pipeline de cerca de $\mathbf{R} \$ \mathbf{1 0 . 0 0 0 , 0 0}$ (dez mil reais).

\section{O PAPEL DA UNIVERSIDADE}

Mais que qualquer outro setor da sociedade, a universidade brasileira desempenha um papel muito pequeno no âmbito da propriedade industrial frente ao que ela poderia desempenhar.

Em primeiro lugar, gostaria de comentar a figura da universidade brasileira como usuária do sistema de patentes.

Apesar de ser muito difícil de se obter dados estatísticos precisos sobre o tema, posso afirmar que, com base em informações obtidas com colegas que atuam na área de propriedade industrial, da totalidade dos pedidos de patente depositados no nosso país por universidades, praticamente todos são de instituições estrangeiras. Ou seja, a universidade brasileira não tem o "hábito" de proteger os objetos de suas atividades de P \& D por meio de patentes.

Isso é lamentável. Conheço bem alguns pesquisadores da UFRJ (uma amostra bem representativa do todo) e sei que seus conhecimentos e sua capacidade nada ficam a dever aos seus colegas do exterior. Aliás, acho que os nossos "inventores" são até mais engenhosos que os seus pares estrangeiros, pois, na maioria das vezes, o pesquisador brasileiro não dispõe dos mesmos recursos e facilidades que o pesquisador do "primeiro mundo" dispõe.

Além disso, como estudante universitário, pude vivenciar a crônica carência de recursos de que a universidade brasileira em geral, e a UFRJ em particular, padece. Desse modo, considero que não explorar a possibilidade de se obter recursos por meio da venda e/ou do licenciamento de tecnologia gerada dentro da universidade seja um desperdício estupendo. Seria bem menos desgastante e muito mais eficiente se, ao invés de somente ficar exigindo verbas do governo, a universidade procurasse a alternativa do patenteamento do seu melhor produto: a inteligência de seus pesquisadores. No entanto, antevejo problemas de natureza política e ideológica dentro da própria universidade que, acredito, dificultarão o atingimento desse objetivo.

Em segundo lugar, gostaria de ressaltar a atuação da universidade como agente da propriedade industrial.

Até o advento da antiga lei de propriedade industrial (Lei 5.772, de 21.12.71), havia, em nosso país um profissional chamado agente da propriedade industrial, cuja formação, regulamentação e reconhecimento profissional ficava a cargo do DNPI (antigo nome do INPI). Quando essa lei foi promulgada, foi estabelecida uma controvérsia legal, que perdura até hoje, colocando em dúvida a continuidade da existência desse agente. Esse profissional, que existe nos Estados Unidos e em muitos países europeus, possui, em sua formação, uma base jurídica sólida aliada a conhecimentos técnicos nas áreas da Química, da Física e das demais ciências naturais, estando apto para atuar na elaboração de pedidos de patente, de registro de marcas e de contratos de transferência de tecnologia. Ora, a universidade brasileira, e a UFRJ em particular, forma advogados, químicos, físicos, engenheiros, médicos, biólogos, dentistas, enfim, praticamente todos os profissionais capazes de, pelo menos em parte, opinar em questões de propriedade industrial.

Aqui, vejo que existe uma lacuna acadêmica que poderia ser preenchida pela universidade brasileira: a de formar, em parceria ou com a supervisão do INPI, uma nova geração de agentes da propriedade industrial. Isso poderia se dar a nível de pós-graduação ou, no meu entender preferivelmente, a nível de graduação. Criar-se-ia, assim, um novo curso multi-disciplinar destinado a formar aqueles profissionais.

E mais, por que não a própria universidade não poderia atuar como agente da propriedade industrial, para elaborar e acompanhar os seus próprios pedidos de patente e de registro de marca? Creio que é mais uma questão de planejamento e de administração, a cargo das esferas dirigentes da universidade, do que de competência, a criação de um centro universitário de pesquisas na área de propriedade industrial ou, melhor ainda, de uma Faculdade de Propriedade Industrial. Uma faculdade desse tipo, poderia formar (e reciclar) não apenas agentes da propriedade industrial, mas também, advogados especializados no assunto e (por que não) examinadores de patentes e de marcas.

Existe outro papel que a universidade pode desempenhar no setor da propriedade industrial: o de instituição depositária de microorganismos.

Posso falar com conhecimento de causa, pois minha formação acadêmica de engenheiro químico foi voltada para essa área, que os pesquisadores na área de Microbiologia Industrial da UFRJ são profissionais extremamente competentes. Acredito que em outras universidades brasileiras haja profissionais de igual quilate.

Assim sendo, também aqui não falta competência para se criar, nas universidades brasileiras, bancos de microorganismos, não apenas para fins de patente, mas para qualquer finalidade pacífica aplicável.

Há alguns anos, tive a oportunidade de conhecer um centro de pesquisas na área de Microbiologia, localizado em Campinas (SP): a Fundação Tropical de Pesquisas e Tecnologia "André Tosello". Naquela ocasião, eles já estavam plenamente capacitados a funcionar como instituição depositária, mesmo porque já dispunham de um considerável acervo de microorganismos (leveduras, bactérias e outros). Apesar da seriedade, da organização e da capacitação técnica de seus funcionários, não vi nada ali que não pudesse ser implementado em qualquer outro lugar, por pessoas que se dispusessem a fazer algo semelhante. 
O setor universítário bem poderia atuar no sentido de pressionar o governo brasileiro a assinar o Tratado de Budapeste, a fim de que as eventuais instituições depositárias pudessem gozar, na totalidade, de seus benefícios.

Portanto, esse é mais um serviço que a Universidade brasileira tem condições de oferecer à sociedade na área de propriedade industrial.

Além disso, com o advento do MERCOSUL, acredito que o surgimento de um acordo regional envolvendo os quatro países membros na área de patentes não tardará e, com a capacitação técnica que o nosso país possui, poderíamos dar uma contribuição notável aos nossos vizinhos se algumas de nossas universidades olhassem com mais interesse e se dispusessem a explorar as imensas potencialidades que o sistema de patentes, em particular, e a propriedade industrial, em geral, oferecem.

\section{ENDEREÇOS ÚTEIS}

Como em todas as categorias, existem bons e maus profissionais na área de propriedade industrial. No entanto, quando houver a necessidade de se utilizar dos serviços de um escritório especializado no assunto, recomendo um contato com a ABAPI ou com a ABPI. Apesar de não serem infalíveis, essas instituições possuem listas de afiliados reconhecidos por sua idoneidade e poderão recomendar alguns escritórios de tradição e competência no mercado. Além disso, por todas as vantagens óbvias inerentes, recomendo uma visita ao site do INPI na rede mundial de computadores INTERNET.

- Associação Brasileira dos Agentes da Propriedade Industrial (ABAPI)

Avenida Franklin Roosevelt, 23 / sala 1305

tel.: (021) 262-3198

- Associação Brasileira da Propriedade Intelectual (ABPI) Avenida Franklin Roosevelt, 23 / sala 802

tel: (021) 220-4879

- Instituto Nacional da Propriedade Industrial (INPI)

Praça Mauá, 7

tel.: (021) 271-5511 (Geral).

tel: (021) 271-5890 (CEDIN - Centro de Documentação e Informação Tecnológica).

\section{- Endereço do INPI na INTERNET}

http://www.bdt.org.br/bdt/inpi (só para busca de pedidos de patente publicados a partir de 1992, decorrente de convênio entre o INPI e a Base de Dados Tropicais da Fundação André Tosello).

http://www.inpi.gov.br (contém informações gerais sobre o INPI, a íntegra das leis atual (9.279) e antiga (5.772), tabelas de retribuições atualizadas, Atos Normativos, entre muitas outras informações).

- Endereço do USPTO (United States Patent and Trademark Office) na INTERNET

http://www.uspto.gov (entre outras informações, estão disponíveis os endereços de várias repartições de patente ao redor do mundo).

- Endereço da IBM na INTERNET - http://www.ibm.com

\section{O SISTEMA DE PATENTES E A INDÚSTRIA FARMACÊUTICA}

Existe um outro mito, relativo à nova lei de propriedade industrial, muito divulgado por determinadas correntes políticas, cuja lógica se baseia em raciocínios um tanto tortuosos e que, confesso, me são de difícil compreensão, qual seja aquele que afirma que os preços dos medicamentos iriam disparar se a legislação brasileira concedesse patentes para os produtos e processos farmacêuticos.
Com relação a isso, permito-me fazer algumas ponderações sobre alguns fatos que pude observar ao longo de minha curta carreira profissional.

Em primeiro lugar, por força da imensa quantidade de capital investido para o desenvolvimento de uma nova molécula farmacêutica, não existe mercado nacional que, sozinho, propicie um retorno desse investimento dentro do prazo de obsolescência dos fármacos. Portanto, os laboratórios farmacêuticos têm que atuar, necessariamente, em mais de um país para obter recuperar o dinheiro por eles investido; atuar de forma protegida, diga-se de passagem.

Em segundo lugar, por maior que seja o laboratório, não há qualquer um que seja dono absoluto de uma determinada fatia do mercado correspondente a uma especialidade médica: ninguém é dono do mercado de antibióticos ou de medicamentos para o coração, por exemplo. De fato, existem poucos, mas eles não estão sozinhos. Portanto, por menor que seja, existe competição pela hegemonia dentro de tais fatias de mercado.

Em terceiro lugar, mesmo que houvesse um único grande laboratório dominando o mercado a ponto de fixar o preço de uma dada nova molécula, haveria um limite superior para tal preço: aquele que o mercado estivesse disposto a pagar. Não adiantaria impor um preço irrealisticamente elevado, tal nova molécula encalharia nas prateleiras das farmácias. Além disso, não é preciso ser um gênio em administração para entender que um incremento na receita das vendas de um bem pode ser obtido por aumento da quantidade vendida e não, necessariamente, pelo aumento do preço unitário desse bem. Creio que um mercado de mais de 50 milhões de pessoas com condições de comprar um medicamento (sendo bem pessimista...), como é o nosso, não é de se jogar fora.

Em quarto lugar, mesmo que a ganância predominasse e os preços dos remédios baseados em novas moléculas disparassem, haveria sempre os medicamentos alternativos até então existentes no mercado, não tão eficientes, porém mais baratos.

Em quinto lugar, apenas o Brasil e mais alguns dois ou três países da África e da Ásia, de nenhuma expressão econômica, até o advento da nova lei sobre patentes, se negavam a conceder patentes para produtos e processos farmacêuticos. Estávamos, pois, na contra-mão do mundo.

Finalmente, em sexto lugar, porém não menos importante, é um fato que práticas como o cartel e o truste existem em nosso país; não sou inocente ou estúpido o suficiente para negar isso. Cabe, aqui, uma pergunta: o que a legislação de propriedade industrial tem a ver com essas práticas? Nada. Isso deveria ser objeto de uma lei anti-cartel ou anti-truste específica, com a autarquia correspondente atuando de modo duro e exemplar para reprimir tais práticas nocivas às economias ditas liberais. Querer atribuir à nova lei em estudo essa responsabilidade é querer tampar o sol com a peneira; ela pode ter alguns defeitos, mas certamente esse ela não tem.

$\mathrm{Na}$ verdade, no meu entender, a nova lei, numa economia saudável, contribuiria para diminuir o preço dos medicamentos por uma razão muito simples: o Brasil, agora, mais do que um grande mercado é um mercado seguro. Um laboratório, que tenha investido a quantidade de dinheiro fabulosa que é gasta para a P \& D de novas moléculas, poderá lançá-las em nosso país sem o risco de que elas sejam copiadas e vendidas um pouco mais barato por outros laboratórios, que pesquisam pouco ou quase nada de novo. Aliás, quem será que lucra de modo mais exorbitante: o laboratório que coloca uma molécula nova no mercado a um preço elevado, decorrente de um grande esforço (tempo e dinheiro) em pesquisas, ou o laboratório que investe apenas na engenharia reversa e na formulação dessa molécula nova e vende o medicamento assim obtido pela metade do preço?

Até a nova lei, não havia a figura do pirata no que se refere às patentes farmacêuticas pelo simples fato de que essas não existiam; era perfeitamente lícito copiar. Hoje, não. 